\title{
Miten yhteiskunnallista traumaa käsitellään?
}

Anteeksipyytäminen ja -antaminen herättää voimakkaita tunteita. Tämä tuli selväksi vuonna 2019, kun entinen koomikko ja nykyinen kansanedustaja Pirkka-Pekka Petelius (vihr.) pyysi anteeksi sekä saamelaisia että romaneja pilkkaavia sketsejään (Rasmus 2019; Näveri 2019). Syntyi kohu, jossa kyseenalaistettiin Peteliuksen tarve pyytää anteeksi - myös kolmansien osapuolten toimesta. Anteeksipyynnön tarpeettomuutta kommentoivat niin kansalaiset kuin poliitikotkin, mutta jossain määrin myös anteeksipyynnön kohteet (Näveri 2019). Kysyttiin ikään kuin historiallista revisionismia vastustaen, että miksi vanhoja asioita täytyi näin kaivella. Monelle ajatus siitä, että menneitä kaiveltiin nykyajan mittapuulla, tuntui liioitetulta.

Vaikka tapaus saattaa vaikuttaa melko triviaalilta, on sen taustalla laajoja, ennen kaikkea poliittisia kysymyksiä siitä, miten tiedostamattaankin yhteiskunnallisessa valta-asemassa (ts. valtaväestöä edustava koomikko kansallisella televisiokanavalla) toimineet saattavat arvioida aiempaa toimintaansa uudelleen. Tässä kontekstissa anteeksipyyntö ei ole ainoastaan subjektiivinen teko, vaan se koskettaa yhteiskuntaa laajemmin - vähintään siinä laajuudessa, kuin anteeksipyynnön aihe on yhteiskunnallisia ryhmiä koskettanut. Näin keskusteluun tulevat vedetyksi myös ryhmät, jotka katsovat että asia ei heitä ole koskenut, eikä siten voi koskea nytkään. Tyypillisesti anteeksiantaminen on ollut poliittisesti ehdollista, mutta myös anteeksipyytäminen on poliittinen tai ainakin poliittisesti arkaluonteinen teko. Kuka pyytää keitä edustaen anteeksi keneltä?

Anteeksipyyntöjen ja -antamisen filosofiaa sekä poliittisia käytänteitä avataan Jan Löfströmin toimittamassa teoksessa Voiko historiaa hyvittää? Historiallisten vääryyksien korjaaminen ja anteeksiantaminen (Gaudeamus: 2012). Tuomas Forsberg (2012) ja Heino Nyyssönen (2012) käsittelevät omissa artikkeleissaan poliittisia anteeksipyyntöjä yksilöiden välisistä suhteista valtioiden väliselle tasolle nostettuina. Yhteiskunnallinen anteeksipyytäminen ja -antaminen tapahtuu kuitenkin myös hyvin henkilökohtaisella tasolla, etenkin kun puhutaan maan sisäisistä, jaetun yhteiskunnan traumoista. Politiikka-lehden numerossa 1/2020 julkaistiin professori Molly Andrewsin (2020) suomeksi käännetty artikkeli, joka käsitteli poliittisen anteeksiannon narratiivista rakennetta henkilökohtaisissa suhteissa. Anteeksipyyntöjen mekaniikkaa tutkivat ovatkin luonnehtineet, että elämme "anteeksipyyntöjen aikakautta" (esim. Andrews 2020; Forsberg 2012, 61; Misztal 2011).

Professori Andrewsin artikkeli havainnollisti, miten monipuolisin tavoin ihmiset reagoivat anteeksipyyntöihin ja anteeksianatamiseen entisen Itä-Saksan (DDR) salaisen poliisin Stasin informanttien ja näiden kohteiden kohtaamisissa eri ajankohtina Saksojen yhdistymisen jälkeen. Anteeksipyytämisen ja -antamisen mekaniikka on monimutkainen silloinkin, kun osapuolten moraalisia asemia voidaan ulkopuolelta katsoen pitää selvinä: kansalaisten toimiminen toisia kansalaisia vastaan autoritaarisen ja jopa sortavan hallinnon nimissä voidaan nähdä yhteiskunnallisena traumana, joka täytyy sovitella jotenkin, jotta yhteiskunta pystyy eheytymään ja jatkamaan eteenpäin (Misztal 2011).

Andrewsin artikkeli osoittaa, että näkemys eheyttävästä vuorovaikutteisesta anteeksipyynnöstä ja -annosta voi kuitenkin olla liian idealistinen, sillä osapuolten väliset suhteet ovat usein 
monitahoisia - voi olla jopa epäselvyyttä siitä, mitä oikein pyydetään anteeksi, onko olemassa anteeksiantamisen velvollisuutta, ja miten hyvitys voidaan kestävästi määritellä, kun kyseessä on kollektiivinen kokemus vääryydestä. Menneisyyden ongelmat halutaan jättää menneisyyteen ja tilit niin sanotusti rauhanomaisesti tasata ja vääryydet oikaista. Tällöin kuitenkin taustalla olevat rakenteet voivat jäädä kasvottomiksi:

Vaikka kysymykset anteeksiannosta tulevat useimmiten esiin ihmisten välisissä suhteissa, on Saksan tapauksessa erittäin vaikeaa erottaa yksittäisten henkilöiden vahingonteot diktatuurin määräämistä toimista. (Andrews 2020, 60)

Vuosikymmenien tai jopa pidemmän ajanjakson aikana kertynyt valta-aseman väärinkäyttö on vaikeaa "tyhjentää" yhteen hetkeen, jossa pyydetään ja annetaan anteeksi ainoastaan instituutioiden tasolla. Trauman aiheuttaja luonnollisesti haluaa anteeksiannon - synninpäästön voidakseen jatkaa elämäänsä tai toimintaansa. Tätä voidaan pitää myös kansankunnan tai kansallisvaltion eduksi ymmärrettävänä askeleena eteenpäin. Halutaan rakentaa uutta kansallista konsensusta ja siten tietä eteenpäin, eli toimia historiallisena taitekohtana "ennen" ja "jälkeen" välillä. Kansakunnan edistysmielinen "eteenpäin työntäminen" voi siis piilottaa taakseen taustalla vaikuttavien prosessien sotkuisuuden sekä epäoikeudenmukaisen valta-aseman mahdollistaneiden rakenteiden puutteellisen purkamisen. Vääryyden kokeneet saatetaan ikään kuin velvoittaa tähän - anteeksiantamaan kollektiivisen hyvän nimissä ilman aitoa vuoropuhelua tai aitoa sovitusta (Andrews 2020, 67).

Anteeksianto on kuitenkin yleensä tavoittelun arvoista, koska se vapauttaa traumaattisen menneisyyden otteesta ja tukee yhteisön rakentumista uudelleen trauman jälkeen. Anteeksiannon välineinä on käytetty esimerkiksi erilaisia totuuskomissioita (Andrews 2003; Hentilä 2005; Ahonen 2018), jotka tyypillisesti on järjestetty melko pian tapahtuneen trauman tunnistamisen jälkeen. Totuuskomissioita ei yleensä hyödynnetäkään maiden välillä, vaan maiden sisällä.

Totuuskomission keskeisin tehtävä on monesti pyrkiä korvaamaan menneisyydessä aiheutuneet vääryydet ja epäoikeudenmukaisuudet. Toisin kuin historiankirjoituksen, totuuskomission haastava tehtävä on määrittää jonkinlainen jaettu "totuus" tapahtuneesta - vaikka se tarkoittaakin usein eri asioita eri ihmisille ja ryhmille (Hentilä 2005). Toisaalta, kuten esimerkiksi Etelä-Afrikan ja Chilen totuus- ja sovintokomissioiden välisistä eroista huomataan (Ahonen 2018), toisinaan prosessin keskeisimmäksi tehtäväksi nouseva ihmisoikeusrikkomusten tunnistaminen ja uhrien oikeudentunnon huomioiminen luonnollisesti vaikeuttaa entisestään sovintoon ja jettuun "totuuteen” pääsemistä. Tällöin komission työtä kritisoidaan usein riittämättömäksi kompromissiksi.

Kompromissimaisuutta selittää se, että totuuskomissio toimii anteeksiannon ja -pyytämisen alustana. Käytännössä totuuskomissiot voivat jäädä melko etäisiksi; esimerkiksi Itä-Saksan totuuskomissio (Andrews 2020, 65, ks. myös Andrews 2003) ei ollut tyydyttävä paikka henkilöiden väliselle vuoropuhelua edistävälle kohtaamiselle. Toisaalta totuuskomissio ei ole myöskään oikeudenkäyntiin verrattava prosessi.

Hankalammaksi tilanne muodostuu, kun selontekoa, selvitystä tai sovitusta ei tehdä, vaan rakenteet jatkavat olemassaoloaan, eikä niitä voida yksiselitteisesti tuomita diktatuurin tekosina: on paljon hankalampaa käsitellä sitä mahdollisuutta, että liberaali demokratia saattaa sisältää äärimmäisen syrjiviä rakenteita. Näin voidaan katsoa tapahtuneen Yhdysvalloissa, jossa 
orjuuden jälkeisenä aikana afroamerikkalainen väestö pidettiin lainsäädännöllisesti ja valtapolitiikassa alisteisessa asemassa. Koska kyse on sukupolvia ylittäneestä yhteiskunnallisesti epäedulliseen asemaan saattamisesta, monelle amerikkalaiselle esimerkiksi hyvitys korvauksen muodossa kuulostaa perusteettomalta. Esimerkiksi presidentti Obaman valintaa pidettiin todisteena siitä, että Yhdysvalloissa ei ole enää tarvetta tasa-arvoistavalle politiikalle (ks. esim. Valentino ja Brader 2011).

Kuitenkin Yhdysvaltojen historiaa paremmin tunteville on selvää, että afroamerikkalaista väestöä on säännönmukaisesti syrjitty, myös virallisen politiikan siunauksella. Julkisia resursseja on asetettu useaan kertaan epätasa-arvoisesti saataville (Watson Institute for International and Public Affairs 2020). Kyse ei ole ainoastaan edustettavuudesta, vaan hyvin oleellisella tavalla materiaalisen vaurauden synnyttämisessä, esimerkiksi (fyysisen omaisuuden kuten talojen) omistussuhteiden kautta (Richardson 2020).

Susan Neiman (2019) on osaltaan pohtinut olisiko Yhdysvalloissa perusteita lähestyä menneisyyden sovittamista samoin kuin Saksa on menetellyt holokaustin suhteen. Rinnastus natsiSaksaan on ilmiselvästi prvokatiivinen - Neiman tiedostaa, että suurelle osalle amerikkalaisista se menee liian pitkälle. Rinnastusta ei tulekaan ottaa kirjaimellisesti, sillä sodassa kukistetun valtion velvollisuus sovitukseen oikeudenkäynteineen on selvästi erilainen kuin sellaisen valtion kohdalla, jossa valtarakenteet ovat muuttuneet tuskaliaan hitaasti. Thomas Laqueur (2020) nostaa esiin Neimanin kirjan arvostelussaan, että Yhdysvaltojen tapauksessa on kyse suoranaisesti koko kansallisesta historiasta, eikä "vain" kymmenen tai edes kahdenkymmenen vuoden ajanjaksosta - Yhdysvaltain sisällissota ei lopettanut rakenteellista rasismia siinä missä natsi-Saksan häviö päätti holokaustin. Tästä ehkä näkyvimpänä ja kiistanalaisimpana nykyaikaisena todisteena ovat olleet vuosikymmeniä erityisesti julkisilla paikoilla näkyneet entisten Etelävaltioiden muistomerkit. Lisäksi Saksankin tapauksessa sovituksen ja trauman käsittelyn suhteen oli merkittävää eroa entisen Länsi- ja Itä-Saksan poliittis-kulttuurillisessa kontekstissa.

Toisin sanoen, tapaus vaikuttaa vahvistavan sekä Forsbergin että Nyyssösen aiemmin mainittuja näkemyksiä kontekstisidonnaisista prosesseista. Rinnastus kuitenkin korostaa samalla sitä vaikeutta, joka kollektiiviseen sovitukseen liittyy. Neiman myös korostaa, että sovituksen osalta Yhdysvallat on merkittävästi myöhässä niin symbolisesti kuin materiaalisestikin. Koska keskustelut orjuuden sovittamisesta korvauksin eivät ole edenneet, mutta levottomuudet ovat lisääntyneet. Sekä Politico (Souli 2020) että Foreign Policy (Aboueldhab 2020) ovat pohtineet Yhdysvaltojen tarvetta omalle julkiselle ja avoimelle totuuskomissiolle rasistisen menneisyytensä käsittelyyn. Jotain merkittäviä askeleita olisi kuitenkin mahdollista - nykytilanteessa kenties väistämätöntä - tehdä.

Jos näitä askeleita ei oteta, vaikuttaa siltä että viime vuosina erilaiset kansanliikkeet ympäri maailmaa ovat valmiita esimerkiksi turmelemaan ja kaatamaan patsaita, joihin on liitetty kolonialistista tai muiden sortavien valtasuhteiden symboliikkaa. Koska patsaiden kaltaisilla muistomerkeillä ja niiden mahdollisella siirtämisellä ja poistamisella on pääasiassa symbolista painoarvoa, niiden vastustaminen saattaa olla kuitenkin helpommin tavoitettavissa kun syvän, rakenteellisen syrjinnän purkaminen: "Patsaiden poistaminen onkin vain laastari, jolla yritetään parantaa kolonialismin ja orjuuden aiheuttamaa avohaavaa" (Turunen 2020). Siitä huolimatta tilanne on äärimmäisen jännitteinen, sillä monelle patsaat symboloivat myös tärkeää ja arvokasta historiallista perimää. 
Suomessakin on historian painolastia, jota on vaihtelevasti käsitelty. Mitä patsaisiin tulee, nekään eivät ole täysin ongelmattomia, sillä kaupunkitila julkisena tilana ei voi olla epäpoliittista. Sisällissodan jäljiltä marsalkka Mannerheimin patsas ei vieläkään ole Tampereella kaupungin keskustassa. Mannerheimin ratsastajapatsas Helsingissä on vallattu niin Greenpeacen kuin saamelaisten kulttuuria ja oikeuksia puolustavan taiteilija-aktivistiryhmä Suohpanterrorin toimesta. Viimeisimpänä patsaan siirtoa ehdottivat Vasemmistonuoret kesällä 2020 (Kurko 2020). Vakiintuneen yhteiskunnallisen valta-aseman symboleita otetaan näin muutosta ajavien ryhmien käyttöön erilaisiin merkityskamppailuihin meilläkin.

Potentiaaliset anteeksipyynnöt eivät Suomessa ole niinkään ulos- kuin sisäänpäin suuntautuneita. Jänniteitä voidaan löytää historiallisesta poliittisesta kontekstista (sisällissodan arvet tai Suomen ja Natsi-Saksan yhteistyö) tai etnisten vähemmistöjen (saamelaiset) ja seksuaalivähemmistöjen (homoseksuaalisuus määriteltynä rikokseksi 1894-1971, mielisairaudeksi vuoteen 1981 asti) ja valtaväestön välisistä suhteista. Näissä monessa voitaisiin katsoa myös olevan perusteita oikeuksien palauttamiselle tai jopa korvauksille.

Tuomas Tepora (2020) pitää vuonna 1998 aloitettua Suomen sotasurmat 1914-1922 -projektia suomalaisena vastineena totuus- ja sovintoprosesseista. Suomessa menneisyyttä käsittelevät ja valottavat prosessit ovatkin olleet pääasiassa historiantutkijoiden työtä (Hentilä 2005, 9) ${ }^{1}$. Suomessa totuuskomissiot ovat saaneet näkyvyyttä vasta 2010-luvun loppupuolella. Vuoden 2018 alussa perussuomalaiset ehdottivat totuuskomissiota käymään läpi 1990-luvun pankkikriisin seurauksia (Korkki 2018; Määttänen 2018). Asiasta ei tosin ole sittemmin juuri kuultu, joten sen saattaa myös laskea osaksi Laura Huhtasaaren silloista presidentinvaalikampanjaa. Sen sijaan valtionneuvosto on tukenut saamelaisten totuus- ja sovintokomission perustamista, jonka tarkoitus olisi käydä läpi historian tapahtumat ja oppia niistä (VNK 2019). Myös saamelaiskäräjät on hyväksynyt prosessiehdotuksen komission perustamisesta (Wesslin 2019). Jäseniä komissioon on asetettu vuoden 2020 keväällä (Tammela ja Rasmus 2020). Prosessi on hidas, mutta aluillaan.

Kuten muuallakin, prosessin onnistumista on vaikea ennustaa. Totuuskomioissioillakaan ei voida katsoa olevan vakiintunutta, yksiselitteistä roolia (Hentälä 2005). Esimerkiksi prosessin suhdetta monimutkaiseen saamelaisuuden hallinto-oikeudelliseen määrittelyyn (Tervaniemi 2019) ei vielä voida tietää. Samaan aikaan myös suhde Lapin ja muun Suomen välillä säilyy jännitteisenä (Tamminen 2020), vaikka vuonna 2019 keskusteltu arktinen rata - junarata Lapin lävitse Jäämerelle - tuli saamelaisten tyrmäämäksi (Lakkala 2019).

Menneisyyden käsittely ja sovittaminen ovat monitahoisia ja monimutkaisia prosesseja, jotka ovat voimakkaan sidonnaisia kulttuurilliseen ja historialliseen kontekstiin. Tuomas Forsberg $(2012,68)$ huomauttaa, että anteeksipyytäminen on usein yhdistetty heikkouteen (tai sen osoittamiseen), vaikka "anteeksipyytämisessä ei ole itsessään mitään, mikä tekisi pyytäjästä heikon". On kuitenkin selvää, että etenkin poliittinen anteeksipyytäminen ja -antaminen herättävät voimakkaita, joskus epätoivottujakin tunteita - kaikissa osapuolissa.

Traumaattisten jälkimuistojen käsittely vaatii kuitenkin nöyryyttä. Se edellyttää vanhojen tapojen kyseenalaistamista ja nostaa esiin vaikeita kysymyksiä historiastamme. Se haastaa meidät oppimaan, kuinka historiamme määrittelee nykyisyyttämme ja aktiivisesti haastamaan tuon yhteyden. Se voi herättää myös syyllisyyden tunteita ja katumusta. (Turunen 2020) 
Tässä lehdessä julkaistaan kaksi vertaisarvioitua artikkelia. Ensimmäisessä Anne-Maria Karjalaisen, Ilkka Pietilän ja Tuulikki Ukkonen-Mikkolan tutkimusartikkelissa tehdään näkyväksi millaisia ideologisia valintoja Suomen neljä suurinta puoluetta ovat tehneet eduskuntavaaliohjelmissaan suhteessa hyvinvointivaltiokansalaisuusdiskursseihin vuodesta 1991 alkaen. Artikkelissa tarkastellaan erityisesti vaaliohjelmissa tuotettuja kansalaisen poliittisia ja sosiaalisia oikeuksia ja velvollisuuksia sekä kansalaisen ja valtion välistä oikeudellinen sidettä ja sen legitimointia pohjoismaisesta hyvinvointivaltiomallista käytävän kamppailun viitekehyksessä. Kansalaisuustulkinnat ohjaavat yhteiskuntapolitiikkaa ja esimerkiksi määritelmät kansalaisten tarpeista vaikuttavat palvelurakenteeseen. Tutkimuksen menetelmällinen lähestymistapa on kriittinen diskurssianalyysi, minkä avulla pyritään erityisesti löytämään argumentaatiota ja keinoja, joilla vaaliohjelmissa perustellaan kansalaisuustulkintoja. Kansalaisen poliittisiin ja sosiaalisiin oikeuksiin ja velvollisuuksiin liittyen artikkelissa tunnistetaan kaksi diskurssia: palveluiden kohteena olevan kansalaisen ja omatoimisen kansalaisen diskurssit. Kansalaisen ja valtion oikeudelliseen siteeseen ja legitimiteettiin liittyen tunnistettiin kansanvallan diskurssi, joissa puolueiden väliset näkemyserot olivat lähinnä painotuksellisia.

Numeron 3/2020 toisessa vertaisarvioidussa artikkelissa Marja Lindberg, Mikael Nygård, Janne Autto, Axel Rappe ja Emily Gichuchi tutkivat suomalaisen hyvinvointipolitiikan muutoksia lapsiperheiden kontekstissa 2000-luvulla. Huolimatta Suomen universalismin periaatteelle rakentuvasta pohjoismaisesta hyvinvointimallista, epävarmemmat ja vaativammat työmarkkinat sekä valtion tuissa ja palveluissa tehdyt leikkaukset ovat viime vuosina lisänneet lapsiperheiden pahoinvointia, erityisesti pienituloisissa sekä yksinhuoltaja- ja monilapsiperheissä. Artikkeli tutkii hallitusohjelmia analysoimalla miten lapsiperheiden hyvinvointi on konstruoitu poliittisesti Suomessa vuosina 2007-2019. Teoreettisesti analyysi nojaa poliittisten kamppailuiden sekä erilaisten vaikutusvaltaisten ideoiden merkityksen jäsentämiseen politiikassa. Analyysin tulosten perusteella voidaan todeta, että tarkastellun ajanjakson alussa perheiden hyvinvoinnin poliittinen konstruointi kulminoitui pitkälti lapsiperheiden hyvinvointiin ja taloudelliseen asemaan, joiden katsottiin heikentyneen työmarkkinoiden epävarmuuden sekä perhepoliittisten tulonsiirtojen reaaliarvon heikkenemisestä johtuen. 2010-luvun edetessä lapsiperheiden hyvinvoinnin kuvaukset rakentuivat konservatiivisesta lapsiperhemallista modernimmalle perhekäsitykselle samalla, kun tulonsiirtoihin nojaavasta perhepolitiikasta siirryttiin "sosiaalisten investointien" politiikkaan, missä perheiden hyvinvoinnin edistäminen turvataan lähinnä korkealaatuisten palveluiden avulla sekä vanhempien osallistumisella työntekoon.

Numerossa 3/2020 julkaistaan myös kolme keskustelua-artikkelia. Aino Hakovirta tarjoaa kattavan ja havainnollistavasti syntetisoivan kirjallisuuskatsauksen demokratian kypsyyden ja kansallisvaltion vakauden välistä kytköstä tarkastelevasta tutkimuskirjallisuudesta. Katsaus avaa näkymän aihepiirin nykytutkimuksen huomattavimpiin suuntauksiin vuosina 1990-2020 julkaistujen oppialan lehtiartikkeleiden ja muiden relevanttien julkaisujen valossa, arvioiden näiden suuntausten osuvuutta ja keskinäisiä suhteita. Kahden vakiintuneemman suuntauksen - 
demokratiakorosteisen sekä valtiokorosteisen - päämääränä on vahvan demokraattisen valtion kehitysedellytysten mallintaminen, mutta ne näyttäytyvät peilikuvamaisesti toistensa idealistisempana ja realistisempana käännöksenä. Kolmas, toistaiseksi vakiintumattomampi ja tulkinnanvaraisempi post-demokraattinen suuntaus hylkää jo lähtökohtaisesti ajatuksen yleispätevän kytkös-optimin määrittämisestä.

Hannu Lahtinen puolestaan kuvaa artikkelissaan kuinka sosioekonomiset - esimerkiksi yksilön koulutustasoon, ammattiasemaan tai tuloihin liittyvät - erot äänestämistodennäköisyydessä ovat klassinen tutkimuskohde useilla yhteiskuntatieteiden aloilla. Suomessa on tilaisuus aiheen tutkimiseen poikkeuksellisen luotettavasti rekisteriaineistojen avulla. Lahtisen mukaan varsinkin nuorten aikuisten koulutusryhmittäiset äänestysaktiivisuuserot ovat nyky-Suomessa ovat suorastaan hälyttävällä tasolla, ja ne ovat myös kärjistyneet huomattavasti viimeisten vuosikymmenien aikana. Kyselytutkimukset ovat aliarviointeet näitä eroja sosiaalisesta suotavuudesta ja vastaajien valikoitumisesta kumpuavien mittausvirheiden takia. Voimakkaat sosioekonomiset erot kyseenalaistavat edustuksellisen demokratian legitimiteettiä ja representaation toteutumista - sitä kuinka hyvin kansanedustajat edustavat kansaa. Lisäksi äänestämistä voi pitää laajempana indikaattorina yhteiskunnallisesta integraatiosta. Artikkeli pohjaa Lahtisen 27.9.2019 Helsingin yliopistossa pidetyn väitöstilaisuuden lektioon.

Tarja Sepän ja Anni Tervon artikkelissa käsitellään Suomen ja Luxemburgin turvallisuusneuvostokampanjoita kaudelle 2013-2014, joista Suomen kampanja tunnetusti epäonnistui. YK:n turvallisuusneuvoston vaihtuvan jäsenen paikka on tavoiteltu, koska se tuo valtiolle määritelmällisesti lisääntyviä mahdollisuuksia verkostoitumiseen sekä lisääntyneen kansainvälispoliittisen näkyvyyden vuoksi vahvemman statuksen. Artikkelissa tarkastellaan syitä siihen, miksi valtiot tavoittelevat turvallisuusneuvoston vaihtuvan jäsenen paikkaa ja miten ne kampanjoivat paikan saadakseen. Suomen kampanjan epäonnistumisen osalta artikkelissa esitetään, että sen syynä ei ollut liian liberaalien arvojen ja ihmisoikeusnäkökulman painottaminen tai pohjoismaalaisuus. Sen sijaan Suomen kampanjan epäonnistumisen taustalla vaikuttivat myöhäiset kampanjatoimet, ristiriitainen maakuva, epäselvät kampanjaviestit, -teemat ja -motiivit, "business as usual" -asenne, kampanjan vähäinen poliittinen merkitys sekä kilpailijoiden erinomainen suoriutuminen.

Numeron 3/2020 sisältöön kuuluu myös yksi kirja-arvio: Markku Koivusalo arvioi Kurt Sontheimerin (ja Marja Pietikäisen suomentaman) teoksen Hannah Arendt - Suuren ajattelijan elämä (2019: Into Kustannus Oy). Arviossa todetaan, että vaikka Sontheimerin ihailu Arendtia kohtaan käy selväksi, teos käyttää siinä määrin tyhjiä superlatiiveja, että sen nimeksi olisi sopinut paremmin superlatiivien banaalisuus. Koivusalon mukaan Sontheimer onnistuu pikemminkin pelkistämään Arendtin ajattelun (sekä Arendtin itsensä ajattelijana) lähinnä kliseiden ja fraasien tasolle. Teos on pikemminkin kunnianosoitus Arendtin vaikutukselle Sontheimerin omaan ajatteluun, muttei syvenny riittävästi esikuvansa ajatteluun tai elämään tarjotakseen muuta kuin hyvin subjektiivisen ja siten pinnalliseksi jäävän kuvaelman. 


\section{VIITTEET}

1. Suomessa vuonna 2015 perustettu Historoitsijat ilman rajoja Suomessa ry (engl. Historians without borders, ks. https://www.historianswithoutborders.fi/) pyrkii edistämään historiatietoisuutta sekä sen käyttöä osana konfliktinratkaisua.

\section{LÄHTEET}

Aboueldhab, Noha. 2020. The United States Needs a Truth Commission. It Should Be Televised. Foreign Policy, 24.7.2020. https://foreignpolicy.com/2020/07/24/united-states-racism-truth-commission-televise-south-africa-tunisia/. Viitattu 14.10.2020.

Ahonen, Sirkka. (toim.) 2018. Kokemuksia totuuskomissioista. Seminaariraportti Helsingin yliopiston Svenska social- och kommunalhögskolanin juhlasalissa 8.1.2018 järjestetystä seminaarista Kokemuksia totuuskomissioista. HWB Report I, 4/2018. https://vnk.fi/documents/10616/9459306/HistoriansWithout-Borders-Kokemuksia+totuuskomissioista-seminaariraportti-080118, viitattu 13.10.2020.

Andrews, Molly. 2003. Grand national narratives and the project of truth commissions: a comparative analysis. Media, Culture \& Society 25:1, 45-66. https://doi.org/10.1177/0163443703025001633.

Andrews, Molly. 2020. Poliittisen anteeksiannon narratiivinen rakenne. Irinja Bickert (suom.), Politiikka 62:1, 59-68. https://doi.org/10.37452/politiikka.89840

Forsberg, Tuomas. 2012. Poliittisen anteeksiannon rajat ja mahdollisuudet. Teoksessa Jan Löfström (toim.), Voiko historiaa hyvittää? Historiallisten vääryyksien korjaaminen ja anteeksiantaminen. Helsinki: Gaudeamus. 61-87.

Hentilä, Seppo. 2005. Löytyykö totuus komissioista? Historiantutkimus ja totuuskomissiot. Tieteessä Tapahtuu, 23:8, 5-12.

Korkki, Jari. 2018. Perussuomalaisten Huhtasaari: 90-luvun pankkikriisi tarvitsee totuuskomission. Yle 1.1.2018. https://yle.fi/uutiset/3-10001559. Viitattu 14.10.2020.

Kurko, Antti. 2020. Julkinen tila ei ole epäpoliittista ja siksi meillä on pitkä perinne monumenttien kaatamisesta. Voima, 18.6.2020. https://voima.fi/artikkeli/2020/julkinen-tila-ei-ole-epapoliittista-ja-siksimeilla-on-pitka-perinne-monumenttien-kaatamisesta/. Viitattu 21.10.2020.

Lacqueur, Thomas. 2020. While statues sleep. London Review of Books 42:12. https://www.lrb.co.uk/thepaper/v42/n12/thomas-laqueur/while-statues-sleep. Viitattu 14.10.2020.

Lakkala, Aletta. 2019. Saamelaisilta täystyrmäys Vesterbackan Jäämeren rata -suunnitelmille - Saamelaiskäräjät yllätettiin jo toistamiseen. Yle, 9.5.2019. https://yle.fi/uutiset/3-10775103. Viitattu 19.10.2020.

Löfström, Jan. (toim.) 2012. Voiko historiaa hyvittää? Historiallisten vääryyksien korjaaminen ja anteeksiantaminen. Helsinki: Gaudeamus.

Misztal, Barbara. 2011. Forgiveness and the construction of new conditions for a common life. Contemporary Social Science 6:1, 39-53. https://doi.org/10.1080/17450144.2010.534492

Määttänen, Juuso. 2018. Perussuomalaiset ajavat näyttävästi totuuskomissiota, johon voisivat kuulua ihmisoikeusprofessori Martin Scheinin ja "ehkä Levonsalo" - Soitimme molemmille. Helsingin Sanomat 28.2.218. https://www.hs.fi/nyt/art-2000005585475.html. Viitattu 14.10.2020.

Neiman, Susan. 2019. Learning from the Germans: Confronting race and the memory of evil. Allen Lane. 
Nyyssönen, Heino. 2012. Jälkisanat: anteeksianto, muistaminen ja unohtaminen. Teoksessa Jan Löfström (toim.), Voiko historiaa hyvittää? Historiallisten vääryyksien korjaaminen ja anteeksiantaminen. Helsinki: Gaudeamus. 200-218.

Näveri, Anna. 2019. Petelius pyysi anteeksi romanisketsejään - Romanifoorumin toiminnanjohtaja nauroi aikanaan niille itsekin: "Mutta monia ne loukkasivat". Yle 20.12.2019. https://yle.fi/uutiset/3-11129617. Viitattu 19.10.2020.

Rasmus, Linnea. 2019. Pirkka-Pekka Petelius pyytää anteeksi saamelaisia pilkkaavia sketsejään: "Olen valmis keskustelemaan myös muiden vähemmistöjen kanssa”. Yle, 21.11.2019. https://yle.fi/uutiset/3-11079638. Viitattu 19.10.2020.

Richardson, Brenda. 2020. Redlining's Legacy Of Inequality: Low Homeownership Rates, Less Equity For Black Households. Forbes, 11.6.2020. https://www.forbes.com/sites/brendarichardson/2020/06/11/redlinings-legacy-of-inequality-low-homeownership-rates-less-equity-for-blackhouseholds/\#7c38d1c62a7c. Viitattu 14.10.2020.

Souli, Sarah. 2020. Does America Need a Truth and Reconciliation Commission? Politico, 16.8.2020. https://www.politico.com/news/magazine/2020/08/16/does-america-need-a-truth-and-reconciliation-commission-395332. Viitattu 14.10.2020.

Tammela, Linda ja Rasmus, Linnea. 2020. Saamelaisten totuus- ja sovintokomission jäseneksi esitetään muiden muassa lakiasiantuntijoita ja yhteiskunta-aktiiveja - kokosimme perusteluja. Yle 27.5.2020. https://yle.fi/uutiset/3-11371409. Viitattu 14.10.2020.

Tamminen, Jari. 2020. Lappi - Suomen oma siirtomaa. Häiriköt-päämaja. 27.8.2020. https://voima.fi/ hairikot/artikkeli/lappi-suomen-oma-siirtomaa/. Viitattu 14.10.2020.

Tepora, Tuomas. 2020. Kuinka suomalainen yhteiskunta selvisi sisällissodasta? Politiikasta.fi, 12.3.2020. https://politiikasta.fi/kuinka-suomalainen-yhteiskunta-selvisi-sisallissodasta/. Viitattu 14.10.2020.

Tervaniemi, Saara. 2019. Korkein hallinto-oikeus saamelaisuuden määrittelijänä. Politiikasta.fi 17.9.2019. https://politiikasta.fi/korkein-hallinto-oikeus-saamelaisuuden-maarittelijana/. Viitattu 14.10.2020.

Turunen, Johanna. 2020. Black Lives Matter: Rakenteellisen rasismin äärellä. Politiikasta.fi, 15.10.2020. https://politiikasta.fi/black-lives-matter-rakenteellisen-rasismin-aarella/. Viitattu 15.10.2020.

Valentino, Nicholas A. ja Brader, Ted. 2011. The Sword's Other Edge: Perceptions of Discrimination and Racial Policy Opinion after Obama. Public Opinion Quarterly 82:2, 201-226.

Valtioneuvostonkanslia. 2019. Saamelaisten totuus- ja sovintokomission asettaminen. 31.10.2019. https:// vnk.fi/documents/10616/20470117/TSK-mandaatti+31.10.2019_su.pdf/142f27c0-5ae3-10a4-ffd0caf2f4527eb3/TSK-mandaatti+31.10.2019_su.pdf. Viitattu 14.10.2020.

Watson Institute for International and Public Affairs. 2020. Trending Globally: Less to Lean On, Part 2. 11.9.2020. https://www.youtube.com/watch?v=WBVZQqOiF-k. Viitattu 14.10.2020.

Wesslin, Sara. 2019. Saamelaisten totuus- ja sovintoprosessi alkaa Suomessa - myös Saamelaiskäräjät hyväksyi prosessiehdotuksen. Yle 17.12.2019. https://yle.fi/uutiset/3-11121408. Viitattu 14.10.2020. 